\title{
Implementing Quality to Assess the Performance of the Educational System: A Preliminary Case Study at the Libyan University Al Jabal Al Gharbi
}

\author{
By Said Al Ghawiel
}

\begin{abstract}
This article proposes an overview of higher education systems that have adopted a performance-based evaluation model. Our theoretical approach offers some primary concepts related to the field of evaluation and performance. A particular emphasis is placed on the idea of quality that is realised through increased research into quality control and compliance with quality standards within higher education. We have based this on a qualitative survey carried out in Libya, where this evaluation model has been implemented in higher education and which is aiming for an improvement in the academic success of students and a better standing in international rankings.
\end{abstract}

Keywords: Evaluation, Higher Education, Libyan Educational System, Quality.

\section{Introduction}

Higher education is currently recognised internationally as a fulcrum for research into economic prosperity, with strong effects on population development. According to an opinion from the Québec Conseil supérieur de l'éducation (Higher Council for Education) in 1994, higher education is now considered a pillar of not only economic growth, but also overall societal development. In their study of higher education and research in the Mediterranean, Fouchet and Moustier (2010: 26) came to similar conclusions: "The World Conference that was held from 5-8 July 2009 at UNESCO headquarters in Paris focused on the theme "The New Dynamics of Higher Education", meaning its pre-eminence on the development of the education system in general, on sustainable development on a national and international scale and on the establishment of societies founded on knowledge". An evaluation tool appears to be strongly required in order to promote higher education. Rueda and Diaz (2005: 3) are in line with this opinion and state that "evaluation has become the preferred tool of government organisations for directing the actions of the higher education system". The context of higher education has changed considerably over the course of recent decades. According to Lanarès and Poteaux (in Berthiaume and Rege Colet 2018: 9), "these changes have altered views of the role of university and its objective", which can be seen in Europe at the same time through "a significant change in the means of governing higher education institutes with a distinct emphasis on autonomy". However, this gradually granted autonomy is not without benefit for universities: "As a general rule, this autonomy allows institutes to have much more

"PhD Student, CIREL Research Laboratory, Lille University, France. 
room to manoeuvre with regard to their offer of courses and when it comes to managing their finances".

Looking more specifically at training methods in higher education, we have here opted for several additional thematic entries that focus on the quality approach. Poteaux (2013) explains that the Bologna declaration made it possible to create a real European space for higher education, with diplomas recognised using ECTS credits (European Credit Transfer and Accumulation System), and to simplify the mobility of students and teachers who are able to complete part of their course or training in a partner country: "These requirements are uniform across European universities and it is also through this that, for example, the establishment of "quality approaches" and the evaluation of teachers has spread. This has been followed by new challenges for institutes and research professors in economic terms, in terms of governance and in terms of structuring programmes and, as a result, teaching methods" (Poteaux 2013: 5).

Higher education also appears to constitute a strategic tool on which is based the development of society, the solutions to society's problems and its future. Azaryeva et al. (2008: 425), clearly explain that "the development of the intellectual, scientific, technical and economic potential of the state is to great extent determined by the universities". However, Perrenoud (2002: 1) provides a more nuanced opinion: "recent international studies draw attention to the difference between what education systems want to do and what they actually do".

Therefore, education is an investment that necessitates mobilisation of resources and skills. This mobilisation requires a justification process and presentation of accounts that are controlled by decision-makers, which are then examined by all those who have responsibilities in the political, economic, legal etc. sectors. In keeping with this, Perrenoud (2002: 1) specifies that "in an economy affected by budget deficits in public finances and a culture of evaluation that is both simplistic and invasive, it cannot be a surprise that the efficiency of teaching has become a major concern”. In fact, all spending has to be justified in relation to objectives that have been set in advance by public institutes and all those involved in the education process.

In addition, the weight of economic factors currently plays a major role in how the efficiency of the education system is viewed. This economic priority invites us to look at the education system as a societal project that has to meet a range of both financial and scientific limitations. Although the concept of the education system, especially in creating programmes and questions of didactic transposition, falls under the jurisdiction of experts in pedagogy, the involvement of various political, socio-cultural and economic actors must also be taken into account because this makes it possible to measure the effects of policy being carried out by implementing a supposedly objective evaluation of the education system that has been developed.

Our article aims to address the theoretical approaches that make it possible to create a model for evaluating performance on the premise of these analyses. We then use all conceptual supports for an empirical study conducted over two years in the context of Libyan education. We have designed the empirical section by creating a questionnaire that is aimed at different actors in higher education while 
drawing on a case study of our own creation focusing on the University of Al Jabal $\mathrm{Al}$ Gharbi. The methodology chosen for this research is nevertheless separate from the quantitative data collected and is primarily focused on the qualitative approach.

\section{Study of a Selection of Performance Evaluation Concepts}

Our aim here is to concentrate on the concepts and trends of evaluation that question the increase in quality and, in this way, to research increased performance.

\section{The Priority of Evaluation}

According to Rege Colet (2005: 84), "the vocabulary being used for evaluation is both complex and polysemous". Inspired by the work of Van Damme (2004), Rege Colet (2005: 84) takes another look at the categorisation that he established between the processes, the procedures and the different levels of action. This classification makes it possible to clarify the concepts used and organise ideas into a hierarchy that we represent in the following diagram (Figure 1), partially reproduced from Nicole Rege Colet's work:

Figure 1. Evaluation of University Teaching and Management

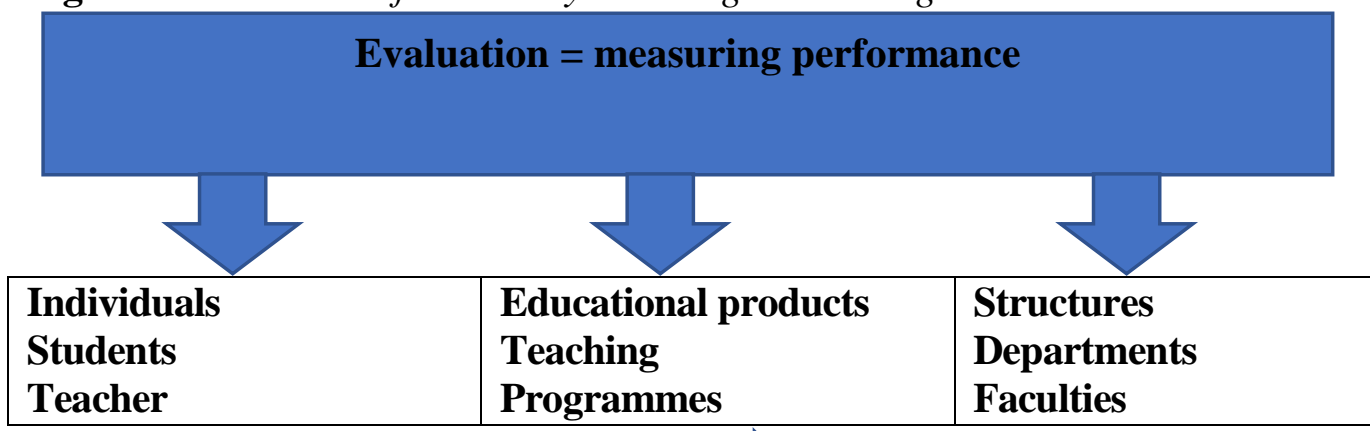

Quality assurance
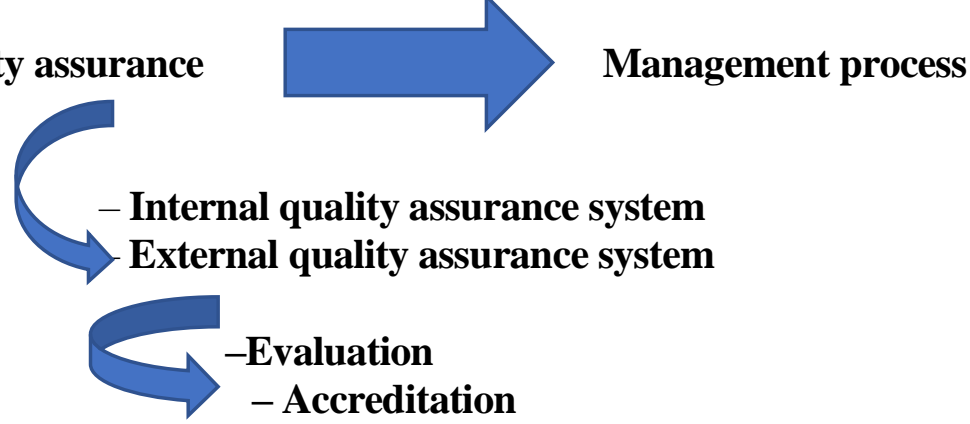

Source: Adapted from Rege Colet (2005: 85).

According to Rege Colet (2005: 85), evaluation concerning higher education applies to all processes that make it possible to measure performance. The author divided them into three levels: the individual level, the curriculum level and the organisational or institutional level. 
$\checkmark$ The first, the individual level, consists of evaluating student performance (evaluating teaching) and teachers' pedagogical performances (evaluating the teacher).

$\checkmark$ The second level deals with educational "products", which include the teaching or programmes provided by a teaching centre. In this case, the measurement focuses on the quality of an education or a programme.

$\checkmark$ Lastly, the third level concentrates on institutional structures and examines teaching and research activities in departments, units, faculties or even universities as a whole. The level of institutional division varies from case to case.

According to Rege Colet (2005: 85), the level of institutional division varies according to the situations faced. In addition, Van Damme (2004) explains that the term quality assurance "refers to processes that aim to evaluate, follow, manage, maintain and/or improve the quality of programmes in training and higher education institutes". According to his analyses, in order to improve teaching, the process of quality assurance has a regulatory role. Furthermore, quality assurance is "at the service of institutional management. It is based on a method organised by institutions to ensure high-quality performances and to direct their strategies and decisions".

Huguette (2011: 10) established six principles to improve the practices of evaluating teaching:

$\checkmark$ Linking the evaluation, improvement and development of teaching to be indistinguishable.

$\checkmark$ Analyse and discuss the quality of a programme being taught using information collected from evaluations.

$\checkmark$ Evaluate teaching in an exhaustive manner by taking into consideration all aspects of teaching and all actions by teachers.

$\checkmark$ Use multiple sources of information and different means of evaluating teaching.

$\checkmark$ Establish rigorous and approved processes for evaluating teaching.

$\checkmark$ Train new teachers in teaching before carrying out an evaluation.

\section{Impact and Direction of Evaluation}

There is clear evidence that "the evaluation of teachers is a complex subject" (Tidiane 2009: 218). Martuccelli (2010: 28-29) also questions the complexity of evaluation, stating that it cannot be considered solely a simple management tool, but that its impact is such that it should be an "actual governance philosophy". He separated eight major explanatory principles (Table 1). 
Table 1. The Principles of Performance Evaluation

\begin{tabular}{|l|l|}
\hline 1 & $\begin{array}{l}\text { Everything can be measured and eventually be evaluated - an exercise that makes it } \\
\text { possible to transform endless ideological debates into technical affairs, thanks to the } \\
\text { creation of potentially competitive sets of indicators. }\end{array}$ \\
\hline 2 & $\begin{array}{l}\text { Everyone has to be evaluated and put in competition with each other - this is in } \\
\text { keeping with greater democratisation and greater objectification of exercising power } \\
\text { in our societies. }\end{array}$ \\
\hline 3 & $\begin{array}{l}\text { Evaluation, insofar as it is based on common frames of references, a high level of } \\
\text { credibility and irreproachable technical criteria, ensures a more transparent } \\
\text { management of power. }\end{array}$ \\
\hline 4 & $\begin{array}{l}\text { Evaluation as a means of management ensures the best possible use of economic } \\
\text { and human resources. }\end{array}$ \\
\hline 5 & $\begin{array}{l}\text { Evaluation increases efficiency as it enables the emergence, in comparison, of good } \\
\text { practices that are made possible by providing recommendations that are more or less } \\
\text { universal (thanks to the logic of benchmarking). }\end{array}$ \\
\hline 6 & $\begin{array}{l}\text { Evaluation creates motivation and consistently involves both organisations and } \\
\text { individuals as they aim to continuously improve in light of the next evaluation. }\end{array}$ \\
\hline 7 & $\begin{array}{l}\text { By making authority more efficient and transparent, evaluation is a powerful } \\
\text { mechanism for legitimising organisations. }\end{array}$ \\
\hline 8 & $\begin{array}{l}\text { By drawing on the consequent limitations of old types of organisational } \\
\text { rationalising, thanks to the reactivity that it ensures, evaluation brings in a new era } \\
\text { of rationalisation to our societies. }\end{array}$ \\
\hline
\end{tabular}

Source: According to Danilo Martuccelli (2010).

These eight principles (Table 2) pose a challenge for the researcher and Martuccelli (2010: 28-29) explores the idea of evaluation by bringing in a critical element.

Table 2. Criticism of the Philosophy of Evaluation

\begin{tabular}{|l|l|}
\hline 1 & Not all practices can be measured equally. \\
\hline 2 & Evaluation is not the same depending on the actors. \\
\hline 3 & Evaluation is not information, but ability. \\
\hline 4 & Evaluation has a cost. \\
\hline 5 & Evaluation is a new kind of performance-related power. \\
\hline 6 & Evaluation is not isomorphic between organisations and individuals. \\
\hline 7 & Evaluation feeds a particular type of legitimacy crisis. \\
\hline 8 & Evaluation is a collective ideology. \\
\hline
\end{tabular}

Belloi et al. (2012: 113) add that evaluation choices put in place in an academic environment are closely linked to "intense production of discussion with properties that are both very homogenous and established on several levels". Taking this into account, what does the term evaluation mean and, more precisely, in what context does it develop a particular aspect? Belloi and his colleagues identify four key elements that they analysed in the context of Belgium:

$\checkmark$ A quality measurement process is regulated by a combination of directives, various protocols, analysis grids and means of presentation. 
The logistics put in place in institutes and at different regional and national levels are sometimes established as "support cells" that provide technical assistance and various recommendations and sometimes as external quality assurance organisations, such as the Agency for assessing the quality of higher education (AEQES) in francophone Belgium.

$\checkmark$ An institutional measure that is increasingly often overseen by a specific department within institutes or an authority created for this purpose (the University of Liège has a dedicated "Quality Management and Support Service").

$\checkmark$ A national and international policy that encourages these approaches following the logic introduced by the Bologna process and that defines challenges on a European level and on a global level, in terms of international rankings for universities.

Alongside functional and organisational aspects linked to the implementation of an evaluation policy, a question is asked about the purpose of the evaluation, ethical principles that underpin it and the consequences that it can bring for individuals and work groups. Mialaret (2004) defends the education process in place and warns against deviations that could trigger an evaluation. He raises three sets of problems in particular:

$\checkmark$ Problems of a philosophical and moral nature: Do we have the right to evaluate and judge someone?

$\checkmark$ The problems with evaluation methods and scientific foundations to which these methods refer (here, all docimological works and contemporary statistical analyses).

$\checkmark$ The aspects that appear to us to be the most important are those caused by considering evaluation within the education process itself, meaning the role played by the evaluation, as well as the level of student-teacher relations in the organisation of the education process.

(Mialaret 2004: 103-104).

For de Gaulejac (2005: 63), performance is defined as the "measurement of results obtained by an individual, a team, an organisation or a process". This measurement of results either penalises or rewards performance. In keeping with this, Saldago (2013) confirms that the notion of performance is combined with the principle of achievement. It is manifested in the effective results of actions, rather than in their planned programme. Chinta et al. (2016: 990) precise that "Performance measures are of a wide variety and are used to evaluate, control, budget, motivate, promote, celebrate, learn and improve".

Managing performance consists of the primary objective of the quality process. Above all, a definition of the notion of performance in a managerial context, then more specifically in the context of teaching, should be agreed upon. However, according to de Gaulejac (2009: 154), "the culture of performance has its pitfalls. Excellence generates exclusion, a forteriori when it is used to sideline some in order to help others to better accept the increased demands of profitability. 
Violence becomes commonplace, as do deteriorating working conditions and developing insecurity, in the race for performance". Researching performance is undoubtedly beneficial, for both the individual and the organisation, because it is a sign of progress. However, obsession linked to the always unsatisfied objective of increased performance must be taken into account and not minimised with regard to the negative effects that it can create.

According to Chinta et al. (2016: 992-993), "Evidently there are many more inputs, processes and outputs than shown above for a higher education institution, and that condition itself calls for use of several metrics in performance management for higher education institutions". We contend, however, despite the extensive diversity of possible metrics, the categories of inputs, processes and outputs provide adequate gestalts for performance management" (Figure 2).

Figure 2. Systems View of Higher Education Institution

\begin{tabular}{|l|l|l|l|}
\hline $\begin{array}{l}\text { Inputs } \\
\text { Students } \\
\text { Faculty } \\
\text { Staff }\end{array}$ & & $\begin{array}{l}\text { Processes } \\
\text { Curricular } \\
\text { programs } \\
\text { Extra- } \\
\text { curricular } \\
\text { Programs }\end{array}$ \\
\hline
\end{tabular}

\section{Research into Quality}

The concept of quality that was discussed during the UNESCO Conference on Education held in October 1998 is defined as follows: "Quality in higher education is a multidimensional concept, which should embrace all its functions, and activities, such as teaching and academic programmes, scientific research, students, buildings, facilities and services, providing social services, internal selfassessment and defining norms in comparison with the quality adopted on a global level". In addition, "the improvement in the quality of teaching and research becomes an increasingly large concern for all involved, especially after the efforts made on a quantitative level: developing the offer and diversifying training plans" (Kaaouachi 2010: 409). According to Mizikaci (2006: 44), "Quality systems recognized by the higher education institutions view the whole organization as a system. Quality approaches suggest that organizations are the systems which essentially consist of input, transformation and output components. Higher education institutions embracing quality systems are viewed in the framework of a systems approach".

Program evaluation suggests a systematic and comprehensive evaluative approach viewing the school organization as an entire system with its programs and functions in practice. Both quality and program evaluation theories are based 
on a holistic approach that incorporates all aspects: functions and forces of a higher education organization, which have interactions and impact on each other. Mizikaci (2006: 45) follows a similar approach, based on the main notion of system: "There are two main points that need to be considered when approaching an evaluation model for quality systems: (1) an evaluative approach should be adopted in the quality systems regarding higher education as a system, and (2) definitions of program evaluation and implementation should be done with quality concepts".

\section{Quality Assurance}

The quality dimension challenges the progress of education. Indeed, Hakkun et al. (2018: 6) notes that: "Quality culture is the key to effective and efficient improvement for educational institutions as an effort to satisfy stakeholders."

According to the European Commission's Tempus programme (2009) ${ }^{1}$, quality assurance has been highly developed in European higher education since the 2000s. According to Détourbe (2014), quality assurance in higher education refers to "the collection of methods that are systematically and institutionally put in place to guarantee and improve the quality of activities within institutes of higher education". Détourbe states further that "these methods include regularly publishing reliable and transparent information, systematically applying processes, implementing different levels of evaluations and also systematically diffusing the results of these evaluations or taking them into account in accordance with a quality control loop" (Détourbe 2014: 51). Furthermore, quality assurance refers to processes that aim to evaluate, monitor, manage, maintain and improve the quality of programmes for training or at higher education institutes (Berthiaume and Rege Colet 2018). In 2007, according to Martin and Stella (2007: 34), UNESCO defined quality assurance as "an all-embracing term referring to an ongoing, continuous process of evaluating (assessing, monitoring, guaranteeing, maintaining and improving) the quality of a higher education system, institutions, or programmes". Moreover, according to Tam (2001: 49), "Quality assurance is a system based on the premise that everyone in an organisation has a responsibility for maintaining and enhancing the quality of the product or service. When put in the university context, quality assurance requires a whole-institution approach for a complete transformation to quality involving top-level commitment, followed by substantial and comprehensive re-education of all personnel. The transformation requires time, effort, and willingness of everyone in the institution to change to a culture which is quality-driven and ever-improving".

\footnotetext{
${ }^{1}$ Tempus is one of several programmes created by the European Community to facilitate the process of economic and social reform and/or development in partner countries. Visit the following website for more detailed information: https://eacea.ec.europa.eu/sites/2007-2013/ tempus-programme_en. The aim of the Tempus programme is to develop higher education systems in these countries through cooperation between institutes in Member States of the European Community.
} 
However, the operationalisation of the concept of quality assurance differs from one country to another and can also reveal significant differences between the United States, Europe and the United Kingdom (Table 3).

Table 3. Implementation of Quality Assurance in the United States, Europe and the United Kingdom

\begin{tabular}{|l|l|}
\hline Countries & \multicolumn{1}{|c|}{$\begin{array}{c}\text { Characteristics of implementing the concept of } \\
\text { quality assurance }\end{array}$} \\
\hline United States & $\begin{array}{l}\text { Accreditation, culture of self-assessment: self-assessment } \\
\text { - external evaluation - publication of reports. Logic of } \\
\text { productivity and profitability. }\end{array}$ \\
\hline European Union & $\begin{array}{l}\text { Comparability (equivalence), diversity of training offers, } \\
\text { student mobility, ENQA (European Association for } \\
\text { Quality Assurance in Higher Education)/SGQA } \\
\text { (Standards and Guidelines for Quality Assurance), need } \\
\text { for homogenous quality. }\end{array}$ \\
\hline United Kingdom & $\begin{array}{l}\text { The Dearing report (1997) focused directly on the quality } \\
\text { of training in higher education, QAA (Quality Assurance } \\
\text { Agency), references, verifying the value of diplomas, } \\
\text { programme specifications, accredited external examiners, } \\
\text { centralised control, quality code for higher education, } \\
\text { conforming to national standards, control of funding } \\
\text { councils, and audits by universities. }\end{array}$ \\
\hline
\end{tabular}

Source: Inspired by Détourbe (2014).

The analysis of characteristics of implementing quality assurance in higher education shows that operationalisation refers to an economic logic in the United States, a transnational, institutional, governmental logic in the European Union (in connection with the Bologna process and the development of a common cooperation network) and a mixed logic that combines the financial and institutional aspects in the United Kingdom. According to Berthiaume and Rege Colet (2018), the notion of quality assurance is theoretically presented as polysemous and requires clarification in terms of definition. In fact, Van Damme (2004) identified four approaches to the concept of quality assurance in higher education, each of which, refer to a type of measure:

$\checkmark$ Measuring excellence.

$\checkmark$ Measuring the consistency between the methods and the objectives (fitness for purpose).

$\checkmark$ Measuring the presence of minimum criteria.

$\checkmark$ Measuring client satisfaction.

\section{Quality Standards in Higher Education}

A variety of researchers have demonstrated the importance of using management tools to study the efficiency of the education system. As Golberg (2002) points it out, "More recently, education leaders have begun to organize the potential for Total Quality Management applied to educational organization". De 
Ketele provides a relatively similar analysis (2018: 23): "The management and regulation of education systems have been affected by changes in a range of contexts, which translates notably into an evolution in the way we think about education and training". In line with this, evaluation has gained popularity on an international scale as an indispensable tool of both public management and regulating educational policy. The objective of evaluation is to produce sufficiently measurable and visible results so as to provide a report on the functioning of education systems and their quality. However, the development of evaluation has seen some major criticisms over the course of recent decades. In addition, de Gaulejac (2009: 291) confirms that "a management ideology kills policy. By recommending a demand for results and efficiency, it shifts the policy into the territory of performance and profitability".

"Evaluation practices and implementing a "quality management"-type approach cause major changes in the management of academic institutes" (Charlier and Vangeebergen 2014: 158). According to Debailley and Pin (2018: 179), "the development of certain evaluation practices and the recent proliferation of rankings have been analysed as a turning point for national higher education and research systems".

On the basis of this, we observe that the notions of quality and efficiency have become reference elements used by international organisations to justify their proposals for reforms and evaluate the degree of modernisation achieved by education systems (Agulhon and Didou-Aupetit 2007: 268).

\section{Practical Study: Local Quality Standards for Evaluating Performance in Higher Education in Libya}

Since the Bologna process, Libya has undertaken a quality management process aimed at increasing the performance of its education system. In addition, the success criteria concerning the quality of diplomas, to which the university must subscribe, enable students to be competitive and perform well on the national and/or international job market and to respond to the needs of the country's human, social, economic and cultural development. However, since 2004, Libya has been involved in a similar process of spreading a culture of quality and devising methods of internal and external evaluation in order to improve governance within its institutes, while encouraging harmonisation with international changes to higher education systems.

\section{The Libyan Educational Context}

The administration of the Libyan education system strongly depends on its complex history and remains closely linked to the existing political system and economic developments. Therefore, the education system has to cope with the numerous and fluctuant challenges the society is facing. Libya has its own education system that reflects its history, identity and regional or global geopolitical transformations. Thus, the education system is taking part of an evolving dynamic. The study presents the evaluation process in higher education 
through the quality approach implemented at the Djebel Al Gharbi University. The quality process began with the promulgation of the Libyan government's decision (official Instruction $\mathrm{n}^{\circ} 141$ - Year 2004) dedicated to the organization of the administrative apparatus of the Ministry of Higher Education. One can observe this commitment with the creation of the administrative structure for research management and quality control in higher education. Thus, the phase of the quality assurance application in Libya education has developed gradually since accreditation is no longer limited to higher education institutions, but is including all educational institutions - primary, secondary and technical school systems.

\section{Study Methodology}

We used the theoretical foundations and basic principles of the quality approach in our study. This proved valuable for understanding the tools and design techniques (software) of performance measurement indicators. Based on this theoretical development, we have designed the empirical section by creating an initial questionnaire that is aimed at different actors in higher education. We then move on to semi-structured interviews and created a case study relating to University of Al Jabal Al Gharbi.

The primary methodology chosen for this research is a qualitative stance. Qualitative analysis enables us to better understand the mechanisms of applying the quality approach. Researchers agree that there is no single scientific way to answer our research questions with the necessary scientific rigour. Indeed, the methods need to be adapted to the studied subjects. Research methods are classically divided between qualitative and quantitative perspectives (qualitative approach in opposition - or in complementarity - to the quantitative approach) (da Silva and de Sousa 2016: 172). The methods choices depend on the research question and the associated objectives. As da Silva and de Sousa (2016) point it out: "depending on the initial questions, some research requires a description of the studied phenomena; others need an explanation of the existing relationships between phenomena; or else, the prediction or control of phenomena. Thus, the selection of methods of analysis must take into account the nature of the questions asked". Livet (2005: 229) explains that "the expression 'reasoning by case' may cover very different methods, many of which have not yet been fully explored. The case study qualitative methodology consists, as indicated in the following definition, of "a detailed account of an ongoing phenomenon that arouses interest. It may involve individuals, institutions, events or processes". According to Collerette (1997), the case study can show particularly useful in situations where the aim is to describe how and why sociological phenomena occur, such situations where researchers have little control over the events studied, and at specific moments when attention is focused on real-life context.

To conduct the research, four types of actors in higher education were consulted; they constituted the master data for carrying out this case study: students, professors, employees (administrative staff), scientists.

The data collected in the questionnaires and through the interviews are organised around four main topics, specifically: 
1. The definition and perception of the idea of quality.

2. Infrastructure, accommodation and restaurants and sociocultural activities.

3. Scientific activities, training programmes, job market.

4. National socioeconomic implications and international cooperation.

\section{The Interview Guide and the Selected Population}

The choice of Al Jabal Al Gharbi University can be justified by the security stability in this region of Libya and the easy access to information and logistics (close to the Tunisian border). The purpose of this study is to explore the practices of quality management in a Libyan university.

Lying on the state of the art, I developed a modular interview guide for interlocutors involved in university policy, with different status and functions. This interview guide consists of five to seven questions, depending on the interviewed person. The questions are summarised in the Table 4.

Table 4. Similar or Specific Questions according to the Status of the Interviewed Population

\begin{tabular}{|c|c|}
\hline \multicolumn{2}{|r|}{ Common Questions for the whole interviewed population } \\
\hline Q1 & $\begin{array}{l}\text { According to you, what are the main needs of the Libyan society and its } \\
\text { economy? }\end{array}$ \\
\hline Q2 & How could you define the quality in higher education? \\
\hline \multicolumn{2}{|r|}{ Common Questions asked to the president (and to the professors) } \\
\hline Q1 & $\begin{array}{l}\text { Are there specific recruitment criteria for new teachers? What are these } \\
\text { criteria? }\end{array}$ \\
\hline Q2 & $\begin{array}{l}\text { To what extent is the teachers' participation in scientific events encouraged } \\
\text { by the university? }\end{array}$ \\
\hline Q3 & $\begin{array}{l}\text { Do you have a cooperation strategy for agreements to bring in professors } \\
\text { from other universities on a national and/or international level (visiting } \\
\text { professors)? }\end{array}$ \\
\hline Q4 & $\begin{array}{l}\text { How do you rate the benefits in kind granted to teachers in order to improve } \\
\text { their performance? }\end{array}$ \\
\hline \multicolumn{2}{|r|}{ Deputy Director of Scientific Affairs } \\
\hline Q1 & $\begin{array}{l}\text { Who builds training programs? Who decides on the training offer/degrees? } \\
\text { How to define training needs? And who identifies them? }\end{array}$ \\
\hline Q2 & $\begin{array}{l}\text { Is there cooperation between the university's research centre(s) and socio- } \\
\text { economic institutions? What is the strategy behind these cooperations? }\end{array}$ \\
\hline Q3 & $\begin{array}{l}\text { Is there a strategy for scientific production, and how does the university } \\
\text { motivate the members of the research centre(s) to invest in this direction? }\end{array}$ \\
\hline Q4 & $\begin{array}{l}\text { Does the university follow internationally adopted programs in higher } \\
\text { education? }\end{array}$ \\
\hline \multicolumn{2}{|r|}{ Deputy Director of Administrative and Financial Affairs } \\
\hline Q1 & Is the university financially independent? Or does it rely on state support? \\
\hline Q2 & $\begin{array}{l}\text { Is there an explicit or even implicit strategy that takes into account the } \\
\text { needs expressed in the labour market regarding the skills required? }\end{array}$ \\
\hline Q3 & $\begin{array}{l}\text { How do you rate the amount of the budget allocated for the needs of the } \\
\text { university library? }\end{array}$ \\
\hline Q4 & $\begin{array}{l}\text { How do you rate the amount of the budget allocated for scientific research } \\
\text { within the university? }\end{array}$ \\
\hline
\end{tabular}




\begin{tabular}{|c|c|}
\hline Q5 & $\begin{array}{l}\text { How do you rate the amount of the budget allocated for the quality } \\
\text { approach? }\end{array}$ \\
\hline \multicolumn{2}{|r|}{ Head of Tuition } \\
\hline Q1 & $\begin{array}{l}\text { Is the agreement for the enrolment of new students based on very specific } \\
\text { criteria? What are these criteria? (Competitions, exams, score...)? }\end{array}$ \\
\hline Q2 & Are there any university scholarship students abroad? \\
\hline Q3 & $\begin{array}{l}\text { How do you rate the evolution of the number of students over the last three } \\
\text { years? }\end{array}$ \\
\hline Q4 & $\begin{array}{l}\text { What are the measures offered to the students who obtained high scores in } \\
\text { their university studies? }\end{array}$ \\
\hline \multicolumn{2}{|r|}{ Director of the Quality Bureau } \\
\hline Q1 & $\begin{array}{l}\text { Do you meet difficulties in applying the quality approach? What is the } \\
\text { nature of these difficulties? }\end{array}$ \\
\hline Q2 & $\begin{array}{l}\text { To what extent does the application of the quality assurance system } \\
\text { matches with your objectives? }\end{array}$ \\
\hline Q3 & Does the university develop action plans to improve quality? \\
\hline Q4 & $\begin{array}{l}\text { What are the measures offered to the students who obtained high scores in } \\
\text { their university studies? }\end{array}$ \\
\hline Q5 & $\begin{array}{l}\text { Does the university develop evaluation plans? And what are the criteria for } \\
\text { such an evaluation? }\end{array}$ \\
\hline Q6 & $\begin{array}{l}\text { Does the university adopt a communication strategy with students, } \\
\text { educational leaders and society regarding these action plans? }\end{array}$ \\
\hline \multicolumn{2}{|r|}{ Director of the Housing and Restoration Office } \\
\hline Q1 & What are the criteria adopted for granting student accommodation? \\
\hline Q2 & Is there a proposed system for university catering? \\
\hline Q3 & Does the university conduct medical examinations for catering staff? \\
\hline Q4 & $\begin{array}{l}\text { Is there any annual maintenance and rehabilitation work for the university } \\
\text { residences? }\end{array}$ \\
\hline \multicolumn{2}{|r|}{ Director for Training } \\
\hline Q1 & Are there programs to improve the skills qualities of public servants abroad? \\
\hline Q2 & $\begin{array}{l}\text { Are the training courses offered according to the needs of the university, in } \\
\text { terms of developing the skills of civil servants? What are the methods used } \\
\text { to evaluate the skills adopted? }\end{array}$ \\
\hline Q3 & Does the university use its training records as a guide for future programs? \\
\hline Q4 & $\begin{array}{l}\text { Is the training built in such a way that qualified civil servants can take on } \\
\text { responsibilities? }\end{array}$ \\
\hline \multicolumn{2}{|r|}{ Director of the Office of Cultural, Social and Sports Activities } \\
\hline Q1 & What are the proposed activities? \\
\hline Q2 & Who is the target audience for your activities? \\
\hline Q3 & Does the university support these activities? \\
\hline Q4 & Is the quality of these activities assessed by the university? \\
\hline \multicolumn{2}{|r|}{ Questions for Students } \\
\hline Q1 & $\begin{array}{l}\text { Do you consider that the university's infrastructure is conducive to the } \\
\text { development of your scientific, cultural and sporting capacities? }\end{array}$ \\
\hline Q2 & How do you rate the quality of housing and catering services? \\
\hline Q3 & $\begin{array}{l}\text { What do you think about the link between training programs and labour } \\
\text { market needs? }\end{array}$ \\
\hline
\end{tabular}




\section{A Context Favourable to the Quality Approach}

In light of recent global changes, the Libyan Ministry for Higher Education is committed to creating a National centre for quality assurance and accreditation in teaching and training institutes. This organisation is dedicated to the development of standards for performance in universities and monitoring the performance of institutes. This is the body that confirms the approved standards for higher education (Ministry of Higher Education and Scientific Research).

The education system in Libya has seen considerable development over the course of recent years. New decisions were made to establish accreditation standards for higher education institutes, which are now issued by the Centre for quality assurance and accreditation of teaching and training, institutional and programmatic institutes (institutes are accredited by ministerial decree no. 647 of 2016).

The role of accreditation, both institutional and programmatic, is to monitor general reform processes in the sector of national and international education and training in order to improve the quality of education results and to provide education and training opportunities for each citizen that are proportional to his/her individual needs, aspirations and abilities.

This all then ultimately leads to responding to the needs of the State and the prosperity of its economy. Academic accreditation has become the main tool for this. In a policy that aims to improve institutes of education and training, the key objective is to continue development and improvement of the education and training sector. In effect, this is a matter of ensuring that a minimum level of standards are carried out to give students, parents, employees and other countries confidence in a strong and consistent education system. As part of this, accreditation must respond to the needs of all parties concerned.

In 2016, institutional accreditation centres were based on nine standards (Table 5).

Table 5. Institutional Standards of Accreditation for Institutes

\begin{tabular}{|l|l|}
\hline \multicolumn{2}{|c|}{ Standards of institutional accreditation for institutes in 2016} \\
\hline $\mathbf{1}$ & Planning \\
\hline $\mathbf{2}$ & Leadership and good governance \\
\hline $\mathbf{3}$ & Teaching staff; Support staff \\
\hline $\mathbf{4}$ & Teaching programme \\
\hline $\mathbf{5}$ & Infrastructure and support services \\
\hline $\mathbf{6}$ & Student affairs \\
\hline $\mathbf{7}$ & Scientific research \\
\hline $\mathbf{8}$ & Social and environmental services \\
\hline $\mathbf{9}$ & Quality assurance and continuous improvement \\
\hline
\end{tabular}


Table 6. Standards to be adopted in Local Academic Programmes

\begin{tabular}{|l|l|}
\hline \multicolumn{2}{|l|}{ Standards to be adopted in academic programmes in $\mathbf{2 0 1 6}$} \\
\hline $\mathbf{1}$ & Teaching staff and support framework \\
\hline $\mathbf{2}$ & Teaching programme \\
\hline $\mathbf{3}$ & Infrastructure and support services \\
\hline $\mathbf{4}$ & Student affairs \\
\hline $\mathbf{5}$ & Scientific research \\
\hline $\mathbf{6}$ & Quality assurance and continuous improvement \\
\hline $\mathbf{7}$ & Social and environmental services \\
\hline $\mathbf{8}$ & Planning and administrative organisation \\
\hline
\end{tabular}

According to Gustin (2001: 32-33), "these are clearly all the indicators selected in the context of institutional evaluation that are requested if you want a report on the quality of teaching or the institution. However, their abundance does not indicate that the evaluation approach borders on the impossible or even the irrational. In terms of training, certain criteria or indicators are of such an importance that their realisation leads to others in their wake. If an institution is satisfied with the implemented training logics (consistency, relevance, value, foundation), it will, in all likelihood, be in agreement with the methods that it develops for achieving good results. However, the choice of a limited number of significant criteria remains a crucial point to be resolved. The same goes for the standards and thresholds to be reached in their realisation. In addition, the use of expert and professional judgements appears here to be an essential approach. The choice of criteria and norms to achieve, develop over time and space depending on contexts, cultural values and people".

These standards are dedicated to the advancement of academic institutes, their pedagogical efficiency and their quality management. Therefore, the efficiency of education is used as a support for high-level scientific activities, both in research and in passing on knowledge and technologies. This results in a field that makes it possible to evaluate the quality of teaching in higher education institutes and the level of the education's efficiency.

\section{Discussion}

At the end of the interviews conducted with the students (4 in number), professors ( 2 in number), the Assistant Director of Scientific Affairs, the Assistant Director of Administrative and Financial Affairs, the Head of Tuition, the Director of the Quality Office, the Director of the Faculty, the Director of the Housing and Restoration Office, the Director of Training, and the Director of the Activities Office, the obtained results seem likely to help us to improve our research questions and feed the theoretical framework.

The results of this pre-survey can be structured around four main areas: 


\section{The Perception and Definition of the Notion of Quality according to the Actors} of the University

We can approach quality according to a number of key words: approach, tool, improvement, performance, skills, procedures, scientific production, efficiency and objectives.

The analysis of these keywords shows that the word "improvement" is the most frequent in defining the concept of quality according to the different interviewees. This is in line with the concept of quality control assurance, according to which, "Continuous improvement is a key concept of quality". The organization must constantly improve its operations to improve quality. In our opinion, continuous improvement is an approach that corresponds to Deming's wheel, which is structured in four repetitive phases and tends towards infinity in a continuous process. These four phases are planning, execution, verification and action.

Each category of interviewed actors also emphasizes a few specific key words such as tool, approach, performance, scientific development. This shows that the empirical definition of quality also depends on the objectives of the actors involved in the educational process. According to Sallis (2002), this fact is in line with the multiple approaches to the definition of the notion of quality developed by Deming (1986), Juran and Godfrey (1988), Crosby (1979) through a set of general principles.

From the above, quality in higher education, particularly in the case studied, can be defined as "a process of continuous improvement based on an approach aimed at achieving superior performance". Without claiming to generalize this definition, it can nevertheless be considered as a starting point.

\section{Scientific Activities, Training Programmes and the Labour Market}

The results show that since the events of 2011, the situation has become complex in terms of scientific activities, the quality of training programmes and the ability to satisfy the employability of graduates. Scientific productions and activities, seminars, colloquia, and conferences take place at the university, but below the expectations of the various actors. However, according to the Deputy Director of Scientific Affairs, "The university integrates internationally adopted programmes on higher education to be in line with contemporary scientific development". Although the current situation is difficult due to the country's political instability, the university is turning towards the integration of training programmes at the international level. Thus, it appears that the political and economic situation had an impact on the ability to develop training programmes through the university's own pedagogical means.

However, the university has kept its socio-economic role since the events of 2011. The Director of Quality himself confirms that "the university plays a social role by disseminating information from scientific culture for the benefit of different societal categories through the organization of conferences and seminars". As regards coordination with the labour market, it seems that, despite 
the crisis, this approach has been taken into account as indicated in the analysis and interpretation of the above data. On the other hand, the country's political and economic instability has led to an imbalance in the administrative system. Thus, the situation should improve in the near future as confirmed by the manager interviewed.

\section{Infrastructure, Housing, Catering and Socio-Cultural Activities}

We note that the university's infrastructure is generally insufficient. This situation develops a feeling of discomfort observed during direct personal observations, which hinders students' ability to be creative and concentrated. Concerning housing and catering, we can notice that the university offers, overall, a range of housing and catering services that meet students' standards and expectations, resulting in an acceptable level of satisfaction. As for socio-cultural activities, the university organizes cultural and sports activities that create a positive dynamic even involving actors outside the university. Thus, the university plays a role of social responsibility, especially in that time of crisis.

\section{National Socio-Economic Involvement and International Cooperation}

The system of scientific research and technological innovation in Libya has undergone significant changes in recent years, both in terms of structures, programmes and objectives. Thus, according to interviewees, educational programs at the university level made it possible to:

- Contribute effectively to the country's overall and sustainable development.

- Diversify industrial production activities.

- Strengthen the competitiveness of companies.

- Establish a new economy (knowledge-based economy).

- Create better employment opportunities.

However, international cooperation in the fields of education, culture and scientific research appears through bilateral and unilateral agreements. However, since 2011, the situation in Libya has been worsening, following events leading to instability and a difficult financial situation for the University of Djebel in Al Gharbi, the subject of our case study.

\section{Conclusion}

The quality approach has been implementing in a number of countries, including Libya. The theoretical foundations are based on several scientific studies conducted by international researchers in a variety of fields that all originate from management, philosophy and education. The designs of these studies differ, with some strongly highlighting the quality approach insofar as it can advance the organisation and growth of a country's economy, based on performance indicators. 
Others place emphasis on the by-products that this approach can offer in terms of respect for the individual and his/her development.

Our study, centred on the Libyan context of higher education, also shows that minimum conditions are required in terms of internal organisation, financial support, training and room to manoeuvre given to supervisory staff and research professors. The quality approach requires, of course, a political willingness, but this needs to be supported and backed up by a collection of means that make it possible to implement this approach optimally.

The analysis and interpretation of data allows us to produce some initial findings. These research findings show that the quality approach is partially applied in the University of Al Jabal Al Gharbi. In fact, on a formal level, we observed that the university created a post dedicated to quality (Quality Office Director), which indicates that legally, the State has a formal framework for adopting the quality approach within the Ministry of Higher Education. However, on a practical level, we noted that there was a lack of application when it came to these tools and quality principles. In addition, the two most significant points regarding this lack are summed up in the absence of specific training programmes for teaching the application of the quality approach and the lack of a culture of quality. The political crisis in Libya seems to have an impact on the running and quality of teaching, as well as on scientific research. This is partially caused by the lack of resources and funding, which are necessary for cultural and scientific activities and consequently have an impact on the motivation of various actors within the university.

The results of our analysis lead to present some recommendations requiring the creation of study programmes for teaching quality:

- Setting up centres for social development and leisure.

- Better coordination with the job market.

- Increase in remuneration (financial motivation).

- Funding scientific research.

- Creating small projects (linked to research, but also for professional purposes).

- Promoting continuing educatio.

- Developing infrastructures.

\section{References}

Agulhon C, Didou-Aupetit S (2007) Les universités. Quelles réformes pour quelle modernité? Le cas du Mexique. [The universities. What reforms for what modernity? The case of Mexico]. Paris: Éditions Publisud.

Azaryeva V, Stepanov S, Shaposhnikov S (2008) Quality assurance in Russian universities in the context of the Bologna process. Helsinborg: Sweden Lund University. Retrieved from: https://bit.ly/2OczHci.

Belloi L, Bouquiaux L, Durand P (2012) Le discours d'excellence. Rhétorique et idéologie de l'évaluation en milieu universitaire. [The speech of excellence. rhetoric and ideology of evaluation in universities]. In Contrôler la Qualité dans L'Enseignement 
Supérieur, JE Charlier, S Croché, B Leclercq (Eds), 111-134. Louvain-la-Neuve: L'Harmattan/Academia.

Berthiaume D, Rege CN (2018) La pédagogie de l'enseignement supérieur. Repères théoriques et applications pratiques: Tome 1: enseigner au supérieur. [The pedagogy of higher education. Theoretical benchmarks and practical applications: Volume 1: teaching in higher education]. Bruxelles: De Boeck.

Charlier N, Vangeebergen T (2014) Saisir l'évaluation de l'université en actes: interprétations et appropriations des parties prenantes. [Capture university evaluation in action: interpretations and ownership of stakeholders]. In Leurres de la qualité dans l'enseignement supérieur? Variations internationales sur un thème ambigu, $\mathrm{C}$ Fallon, B Leclercq (Eds),157-172. Louvain-la-Neuve: L'Harmattan/Academia.

Chinta R, Kebrichti M, Ellias J (2016) A conceptual framework for evaluating higher education institutions. International Journal of Educational Management 30(6): 9891002. Doi: 10.1108/JJEM-09-2015-0120.

Collerette P (1997) Méthodologie: l'étude de cas au service de la recherche. [Methodology: the case study for research]. Recherche en soins infirmiers 50(Sep): 81-88.

Conseil Supérieur de l'Education (1994) L'enseignement supérieur et le développement économique. [Higher education and economic development] Québec: Bibliothèque Nationale du Québec. Retrieved from: https://bit.ly/2JBPAop.

Crosby PB (1979) Quality is free. London: McGraw Hill.

Da Silva L, de Sousa T (2016) Gestion de la qualité dans la recherche en sciences sociales et humaines: articulation entre les méthodes qualitatives et quantitatives, [Quality management in social and human sciences research: linking qualitative and quantitative methods]. Recherches Qualitatives 18: 171-181.

De Gaulejac V (2009) La société malade de la gestion. [The sick management society]. Paris: Editions du Seuil.

De Ketele JM (2018) L'évaluation des systèmes d'éducation et de formation: enjeux et tensions liés à la qualité éducative. [The evaluation of education and training systems: challenges and tensions related to educational quality]. In Actes $d u 30^{\text {ème }}$ Colloque de l'ADMEE-Europe, 10-12 Janvier 2018, 34-166. Luxembourg: Esch-sur-Alzette.

Debailly R, Pin C (2018) (Se) gouverner \& (s') évaluer. [Govern and evaluate]. In C Barats, J Bouchard, A Haakenstad (Eds), Faire et dire l'évaluation: l'enseignement supérieur et la recherche conquis par la performance. Paris: Presses des mines.

Deming WE (1986) Out of the crisis. Cambridge: Cambridge University Press.

Despreaux D (2010) Avez-vous dit performance des universités? [Did you say university performance?] Paris: L'Harmattan.

Detourbe MA (2014) Les enjeux de l'évaluation dans l'enseignement supérieur -Le cas des universités britannique. [The challenges of evaluation in higher education - The case of British universities]. Toulouse: Presses Universitaires du Mirail.

Fallon C, Feron P (2014) Indicateurs de performance et gestion de la qualité comme outils de gouvernement. [Performance indicators and quality management as tools for governing]. In Leurres de la qualité dans l'enseignement supérieur? Variations internationales sur un thème ambigu, B Leclercq, C Fallon (Eds). Louvain-la-Neuve: L'Harmattan/Academia.

Fouchet R, Moustier E (2010) L'enseignement Supérieur et la Recherche en Méditerranée: Enjeux et Défis de Demain en Sciences Sociales. [Higher education and research in the Mediterranean: challenges and tomorrow stakes for the social sciences]. European Union Institute for Security Studies (EUISS), Institut Europeu de la Mediterrània (IEMed).

Golberg JS, Cole BR (2002) Quality management in education: building excellence and equity in student performance. $A S Q$, The Global Voice of Quality 9(4). 
Gustin A (2001) Management des etablissements scolaires: de l'évaluation institutionnelle à la gestion stratégique. [How to manage schools: from institutional evaluation to strategic management]. Bruxelles: De Boeck.

Hakkun E, Dwi P, Suwasono, Soenarto, Ansari SA, Rusli (2018) A study of VHS culture of quality through improving the role of ICT center management. Journal of Physics: Conference Series 1028, 012066.

Huguette B (2011) Comment evaluer, améliorer, valoriser l'enseignement supérieur? [How to evaluate, improve and highlight higher education?] Bruxelles: De Boeck.

Juran JM, Godfrey AB (1988) Juran's Quality Handbook (5 $5^{\text {th }}$ edition). New York: McGraw-Hill.

Kaaouachi A (2010) L'évaluation dans le système d'enseignement supérieur au Maroc. Bilan des réalisations, limites et principaux défis. [Evaluation in the higher education system in Morocco. Achievements, limits and main challenges], 409-422. In Proceedings of the Arab Regional Conference on Higher Education, Cairo, 31 May, 1-2 June 2009. United Nations Educational, Scientific and Cultural Organization, UNESCO.

Livet P (2005) Les diverses formes de raisonnement par cas. [The various forms of reasoning with case study]. In Penser par cas, JC Passeron, J Revel (Eds). Paris: Editions de l'EHESS.

Martin M, Stella A (2007) Assurance qualité externe dans l'enseignement supérieur: les options. [External quality assurance in higher education: options]. Institut International de Planification de l'Education. UNESCO Publications.

Martuccelli D (2010) Critique de la philosophie de l'évaluation. [Criticism of the evaluation philosophy]. Cahiers Internationaux de Sociologie 1-2(128-129): 27-52.

Mialaret G (2004) La psychopédagogie. [Psychopedagogy] (5 ${ }^{\text {th }}$ edition). Paris: Presses Universitaires de France.

Mizikaci F (2006) A systems approach to program evaluation model for quality in higher education. Quality Assurance in Education 14(1): 37-53.

Perrenoud P (2002) Dix principes pour rendre le système educatif plus efficace. [Ten principles to make the education system more effective]. Genève: Université de Genève.

Poteaux N (2013) Pédagogie de l'enseignement supérieur en France: état de la question [Pedagogy of higher education in France: The state of the question]. Distances et Médiations des Savoirs 4. Retrieved from: https://bit.ly/2JSbN0i.

Rege Colet N (2005) Evaluation des enseignements et pilotage de l'université. [Evaluation of the courses and management of the university]. Education en Débats: Analyse Comparée 3: 83-95.

Rueda M, Diaz BF (2005) Un réseau des chercheurs pour faire face à l'évaluation de l'enseignement universitaire. Une expérience au Mexique. [A network of researchers to deal with the evaluation of university education. An experience in Mexico]. Communication Présentée au Colloque: L'Evaluation dans l'Enseignement Supérieur, Université Paris-Nanterre. Retrieved from: https://bit.ly/2Gi8cb0.

Salgado M (2013) La performance: une dimension fondamentale pour l'évaluation des entreprises et des organisations. [Performance: a fundamental dimension for evaluating companies and organizations]. HAL Id: hal-00842219. Retrieved from: https://hal.archives-ouvertes.fr/hal-00842219.

Sallis E (2002) Total quality management in higher education. London: Kogan.

Tam M (2001) Measuring quality and performance in higher education. Quality in Higher Education 7(1): 47-54.

Tidiane SC (2009). Connaître les perceptions des enseignants à propos de l'évaluation des enseignements, une étape dans le processus de mise en œuvre d'une démarche qualité. 
[Knowing the perceptions of teachers about the evaluation of lessons, a step in the process of implementing a quality approach]. In L'Evaluation de l'Enseignement par les Etudiants, M Romainville, C Coggi (Eds), 211-233. Bruxelles: De Boeck.

Van Damme D (2004) Standards and indicators in institutional and programme accreditation in higher education: a conceptual framework and a proposal. In Indicators for Institutional and Programme Accreditation in Higher/Tertiary Education, L Vlăsceanu, LC Barrows (Eds), 125-157. Bucharest: UNESCO-CEPES. 
